\title{
Pendekatan Marketing Mix Dalam Upaya Meningkatkan Penjualan Rumah Olahan Susu Kelurahan Songgokerto Kota Batu
}

\author{
Sri Wilujeng1 dan Rita Indah Mustikowati, ${ }^{1}$ \\ ${ }^{1}$ Program Studi Manajemen, Fakultas Ekonomika dan Bisnis Universitas Kanjuruhan Malang
}

\begin{abstract}
Abstrak
Rumah Pemberdayaan "Sussu" berdiri atas dasar fenomena yang terjadi di sekitar warganya. Ketersediaan bahan baku yang melimpah karena sapi perah banyak dibudidayakan oleh masyarakat Kelurahan Songgokerto dan terbukanya pasar karena produk oleh-oleh khas Kota Batu sangat diminati oleh para wisatawan. Banyaknya kaum ibu-ibu yang tinggal di sekitar rumahnya dan tidak memiliki aktifitas usaha di tengah himpitan ekonomi yang semakin kuat mendorong penggagas untuk memberdayakan mereka dalam pengembangan usaha pengolahan susu ini. Terbatasnya produk olahan susu berupa camilan di Kota Batu berdampak pada tingginya permintaan pasar tehadap produk yang dihasilkan oleh Rumah Pemberdayaan "Susu" - Batu, akan tetapi usaha ini mengalami kesulitan dalam meningkatkan volume produksinya karena proses produksi masih dilakukan secara tradisional dan monoton. Tujuan kajian ini adalah untuk memberikan pemahaman yang utuh dan komprehensif tentang Manajemen Usaha dalam proses produksi olahan susu serta memberikan pemahaman tentang kreativitas dan inovasi dalam mengembangkan produk susu. Hasil pengabdian ini menunjukkan bahwa warga sekitar dapat diberdayakan secara produktif dan termotivasi mengembangkan usahanya dengan pendekatan manajemen usaha dan inovasi produk dengan cara mengikuti sosisalisasi marketing mix pembuatan aneka olahan susu yang mempunyai nilai ekonomis dan menambah pendapatan keluarga.
\end{abstract}

Kata kunci: Pelatihan, Kewirausahaan, Manajemen Usaha, Inovasi

\section{PENDAHULUAN}

Indonesia merupakan Negara yang dianugerahi kekayaan alam yang berlimpah-limpah. Jika dilihat dari sumber daya alamnya memiliki peluang untuk kesejahteraan penduduknya. Akan tetapi kenyataannya, sebagian besar penduduknya masih hidup di bawah kesejahteraan. Melihat fenomena tersebut maka kita tidak bisa melihat hanya dari satu sisi permasalahan, namun banyak faktor yang menimbulkan kondisi tersebut terjadi. Kemajuan suatu Negara tidak hanya ditentukan oleh ketersediaan sumber daya alam atau modal, namun ditentukan oleh inovasi. Inovasi teknologi berperanan penting dalam menggerakkan roda perekonomian suatu bangsa. Anang Lastriyanto (2016) menjelaskan bahwa inovasi merupakan penerapan ide baru pada produk dan proses (doing new thing) yang didorong oleh cara berpikir kreatif (thinking new thing). Keduanya merupakan bagian yang tidak terpisahkan dan mempunyai alur yang spesifik. Adanya permintaan pasar terhadap suatu inovasi menimbulkan investasi dan penetrasi pasar sehingga memicu pertumbuhan wirausaha dan bisnis baru yang pada gilirannya mendatangkan keuntungan ekonomi. Usaha-usaha yang banyak tumbuh di masyarakat (kewirausahaan) pada umumnya tergolong sebagai usaha mikro, kecil dan menengah (UMKM). Kewirausahaan banyak dipahami berkaitan dengan kreativitas dan inovasi dalam menciptakan ataupun penerapan hal-hal baru dalam dunia usaha, seperti: produk, cara kerja, proses, delivery system, pelayanan, pasar baru, disamping berkaitan dengan karakter dan fungsi manajemen. Inovasi secara mendasar didefinisikan: introduksi ide baru yang mampu memberikan nilai tambah bagi usaha. Inovasi menjadi bagian yang penting dari pengembangan usaha dan jiwa wirausaha. Menurut Peter F. Ducker, fungsi bisnis hanya ada dua, yaitu inovasi dan marketing. Antara kreativitas dengan inovasi tidak dapat dipisahkan, apabila kreativitas diartikan sebagai memikirkan tentang hal baru, maka inovasi diartikan sebagai melakukan sesuatu yang baru (Thedore Levitt).

MEA (Masyarakat Ekonomi ASEAN) telah diberlakukan sejak tahun 2016. Hal ini mengakibatkan pelaku UMKM di dalam negeri harus bisa bersaing dengan UMKM dari negara tetangga. Oleh karena itu dukungan penuh dari pemerintah, pelaku usaha besar dan masyarakat sangat diperlukan untuk mendongkrak pertumbuhan UMKM. Namun, tidak dapat dielakkan lagi semenjak dibukanya Perdagangan Bebas Asean Free Trade Agreement/AFTA- 
China 2010 menimbulkan kekhawatiran di kalangan industri di Indonesia. Terlebih lagi bagi pelaku Usaha Mikro, Kecil Dan Menengah, UMKM menjadi kelompok usaha yang memiliki kekhawatiran yang cukup besar. Dengan dibukanya CAFTA semakin besar barang-barang Cina memasuki pasar yang selama ini menjadi wilayah Usaha mikro, kecil dan menengah. Salah satu jalan untuk meningkatkan daya saing usaha mikro, kecil dan menengah Indonesia adalah dengan meningkatkan mutu produk dan efisiensi produksi dengan adanya penerapan Manajemen Usaha yang baik.

Bagi pelaku usaha kecil, manajemen usaha terkadang dianggap sebuah konsep yang terlalu muluk-muluk. Tetapi sebenarnya tidak demikian, banyak usaha kecil yang sebenarnya memiliki prospek baik akhirnya kandas di tengah jalan karena miss-manajemen atau salah kelola dari pemiliknya. Atau sebuah bisnis usaha kecil yang sebenarnya baik dan memiliki prospek cerah tetapi tidak didukung oleh Manajemen Bisnis yang baik, akhirnya tidak berkembang. Karena itu penting bagi pelaku usaha kecil untuk mencermati dan belajar mengenai manajemen usaha ini. Manajemen sebuah usaha tidak semata-mata keterampilan mengelola tetapi juga sebagai sebuah seni. Dalam manajemen usaha kecil perpaduan antara seni dan keterampilan mutlak diperlukan. Tidak hanya manajemen usaha berlandaskan teori-teori manajemen semata tetapi diperlukan pendekatan dan perlakuan lain yang bersifat holistik.

Pelaku usaha kecil biasanya adalah pemilik usaha yang memiliki fungsi ganda, karena itu manajer dalam usaha kecil berhadapan langsung dengan semua hal yang berkaitan dengan usaha, produksi, sumber daya, pemasaran, pengembangan usaha dan lain-lain. Karena itu kemampuan manajemen mutlak diperlukan sebagai landasan kelangsungan usahanya. Di dalam manajemen usaha kecilada dua hal yang perlu menjadi landasan keberhasilan usaha yaitu Manajemen yang berbasis profesionalisme dan kewirausahaan.

Keduanya merupakan suatu tuntutan yang tidak dapat dihindari oleh setiap pelaku bisnis.Banyak pelaku usaha kecil yang mengeluhkan sulitnya mengembangkan usaha. Usaha yang dirintis mengalami kemandekan pada satu posisi tertentu. Salah satu kunci jawaban dalam mengatasi persoalan tersebut adalah dengan melakukan inovasi, baik inovasi proses maupun inovasi produk. Inovasi produk merupakan salah satu dampak dari perubahan teknologi yang cepat dan variasi produk yang tinggi akan menentukan kinerja organisasi (Hurley \& Hult, 1998). Inovasi yang tinggi baik itu inovasi proses maupun inovasi produk akan meningkatkan kemampuan perusahaan menciptakan produk yang berkualitas. Kualitas produk yang tinggi akan meningkatkan keunggulan bersaing UMKM yang pada akhirnya berdampak pada kinerja usaha. Inovasi merupakan proses teknologis, manajerial dan sosial, dimana gagasan atau konsep baru pertama kali diperkenalkan untuk dipraktekkan dalam suatu kultur (Quinn, Baruch \& Zien, 1996). Inovasi baik inovasi produk maupun inovasi proses merupakan faktor penentu dalam persaingan industri dan merupakan senjata yang tangguh menghadapi persaingan.

Inovasi produk didefinisikan sebagai produk atau jasa baru yang diperkenalkan ke pasar untuk memenuhi kebutuhan pasar (Damanpour, 1991). Lukas \& Farel 2000 membedakan inovasi produk atas tiga kategori dasar, yaitu product line extensions, mee to products dan new to the world product. Product line extensions adalah produk yang relatif baru dipasar namun tidak baru bagi perusahaan. Mee to product adalah produk yang relatif baru bagi perusahaan namun relatif sudah dikenal di pasar. New to the world product adalah produk baru baik bagi perusahaan maupun bagi pasar.

Inovasi proses menggambarkan perubahan dalam cara organisasi memproduksi produk dan jasa akhir dari suatu perusahaan (Cooper, 1998). Inovasi proses merupakan saran untuk meningkatkan kualitas dan juga penghematan biaya. Hal ini mencerminkan bahwa adopsi proses inovasi diakui dapat meningkatkan efisiensi produksi dan kualitas produk yang dihasilkan.

Menurut trilogy Schumpeter, inovasi berkaitan dengan invensi dan difusi. Invensi berkenaan dengan ide baru untuk melakukan atau membuat sesuatu, belum memperhitungkan profit. Inovasi merupakan invensi yang berhasil diterapkan sehingga menghasilkan produk ataupun proses yang secara komersial memberikan nilai/valuable.

Susu merupakan bahan pangan yang mempunyai nilai gizi tinggi karena mempunyai kandungan nutrisi yang lengkap seperti laktosa, lemak, protein, berbagai vitamin dan mineral. Meskipun susu berperan penting sebagai bahan pangan strategis dalam menunjang pembangunan nasional khususnya dalam penciptaan sumber daya manusia yang berkualitas, namun konsumsi 
susu masyarakat Indonesia saat ini masih rendah jika dibandingkan negara Asia lainnya. Berdasarkan data Direktorat Jenderal Pengolahan dan Pemasaran Hasil Pertanian Kementerian Pertanian RI, pada tahun 2011 konsumsi susu masyarakat Indonesia adalah 11,09 liter per kapita pertahun dan pada tahun 2012 naik mejadi 14,6 liter per kapita pertahun. Angka tersebut masih lebih rendah dari Malaysia dan Filipina yang mencapai 22,1 liter per kapita pertahun,Thailand 33,7 liter per kapita pertahun dan India 42,08 liter per kapita pertahun. Penyebab rendahnya konsumsi susu masyarakat Indonesia selain disebabkan oleh masih rendahnya produksi susu nasional yaitu berkisar 1,7-1,8 juta litersetiap harinya, faktor pola hidup dan kesadaran masyarakat akan pentingnya konsumsi susu juga masih sangat rendah. Berbagai upaya terus digalakkan untuk meningkatkan konsumsi susu masyarakat Indonesia, salah satu diantaranya adalah melalui diversifikasi.

Berbagai macam produk olahan susu yang telah dikenal oleh masyarakat antara lain susu pasteurisasi, susu UHT, susu sterilisasi, recombined milk, susu kental manis, susu fermentasi, susu bubuk, es krim, mentega, keju dan lain sebagainya. Dalam rangka meningkatkan konsumsi susu untuk memenuhi kebutuhan protein hewani, perlu dilakukan diversifikasi produk olahan susu sehingga diperlukan penerapan teknologi pengolahan yang tepat untuk mendapatkan produk olahan yang beraneka ragam dengan nilai gizi yang masih baik. Perkembangan teknologi pengolahan telah mengakibatkan perubahan pola makan konsumen yang berdampak pula pada perkembangan teknik produksi dan distribusinya. Produk olahan susu tidak lagi hanya diarahkan pada pengolahan minuman untuk pemenuhan gizi masyarakat melainkan telah bergeser ke arah diversifikasi produk olahan susu untuk makanan ringan (nugget susu, permen susu, stick susu, kerupuk susu) dan kecantikan (sabun susu, masker susu dan lotion susu). Diversifikasi produk olahan susu mutlak dilakukan untuk meningkatkan nilai ekonomis produk disamping untuk menumbuhkan lapangan kerja baru berbasis pemberdayaan di pedesaan.

Di era 90an Kota Batu merupakan salah satu sentra penghasil susu segar terbesar di Jawa Timur. Namun seiring dengan semakin pesatnya perkembangan Kota Batu sebagai daerah tujuan wisata, produksi susu segar semakin menurun karena berbagai faktor antara lain semakin menipisnya lahan hijauan untuk pakan ternak akibat alih fungsi lahan, jumlah populasi ternak yang semakin sedikit dan harga jual susu segar yang relatif rendah akibat tingginya ketergantungan peternak terhadap Industri Pengolahan Susu. Jika hal ini terus berlanjut, maka lambat laun peternak akan merugi dan usaha peternakan sapi perah akan ditinggalkan.

Mensikapi kondisi di atas dengan melihat setiap peluang yang ada, Rumah Pemberdayaan "Sussu" - Batu berinisiatif untuk mengembangkan usaha pengolahan susu segar menjadi berbagai produk olahan susu yang memiliki nilai ekonomis tinggi. Usaha ini dikelola menggunakan konsep pemberdayaan masyarakat berbasis ekonomi kerakyatan dengan fokus utama memberikan lapangan kerja dan kesempatan berusaha kepada masyarakat ekonomi lemah sehingga terangkat perekonomian keluarganya. Pengolahan susu dipilih sebagai domain usaha mengingat Kelurahan Songgokerto merupakan salah satu daerah penghasil susu segar di Kota Batu yang masih bertahan hingga saat ini. Banyaknya wisatawan yang berkunjung ke Kota Batu memberikan peluang yang cukup menjanjikan dalam pemasaran produk yang dihasilkan sehingga kekhasan produk olahan susu yang dihasilkan diharapkan mampu bersaing di pasaran.

Keberadaan Rumah Pemberdayaan "Sussu" Batu berjalan karena adanya kebutuhan untuk maju bersama-sama dalam meningkatkan taraf ekonomi keluarga di tengah sulitnya mencari lapangan pekerjaan dan kesempatan berusaha khususnya bagi kaum ibu dengan taraf pendidikan yang relatif rendah, usia tidak lagi produktif atau masih mempunyai banyak tanggungan dalam rumah tangga dan sekolah.Rumah Pemberdayaan "Susu" berdiri pada tahun 2011, di Desa Songgokerto Kelurahan Songgokerto Kecamatan Batu, Kota Batu dengan jumlah anggota sebanyak 11 orang yang semuanya adalah kaum ibu (janda, manula, ibu rumah tangga pra sejahtera dan anak-anak perempuan yang mempunyai semangat sekolah tetapi orang tuanya tidak mampu untuk membiayainya) yang berdomisili di Kelurahan Songgokerto.

Produk olahan susu yang diproduksi antara lain permen susu dan es yoghurt, sedangkan produk yang masih dalam tahap uji coba adalah onthok susu dan ting-ting susu. Pendidikan terakhir anggota mayoritas SD (73 persen), 
SLTA (18 persen) dan S1 (9 persen). Aktifitas sehari-hari anggota adalah ibu rumah tangga, pembantu rumah tangga dan buruh tani sehingga aktivitas di Rumah Pemberdayaan "Susu"- Batu merupakan usaha sampingan untuk menambah penghasilan keluarga. Untuk memenuhi kebutuhan produksi dibutuhkan susu segar sebanyak 30 - 40 liter/hari sehingga dihasilkan permen susu sebanyak $10 \mathrm{~kg}$ dan $500-700$ bungkus es yoghurt dengan harga jual $\mathrm{Rp}$. $38.500,-/ \mathrm{kg}$ untuk permen susu dan Rp. 300,/bungkus untuk es yoghurt.

Dalam pelaksanaan produksinya, setiap anggota diberikan kebebasan dalam menentukan waktu dan tempatnya. Rumah produksi hanya digunakan untuk mengerjakan proses produksi yang sifatnya membutuhkan kontrol kualitas dalam tahapannya dan mengumpulkan produk akhir sebelum dipasarkan. Tahapan proses yang tidak membutuhkan kontrol kualitas dapat dilakukan di rumah anggotanya masing-masing sesuai kelonggaran waktu yang dimilikinya.

Pemasaran produk yang dihasilkan oleh Rumah Pemberdayaan "Susu" sedikit berbeda dari UMKM pada umumnya. Selain dipasarkan langsung ke konsumen, produk yang dihasilkan dijual kepada pihak kedua yang telah memiliki nama dagang di pasaran. Langkah ini dilakukan mengingat Rumah Pemberdayaan "Susu" - Batu belum memiliki legalitas usaha. Setiap keuntungan yang dihasilkan masih sebatas untuk memenuhi biaya operasional dan tambahan modal usaha. Masih terbatasnya produk olahan susu berupa camilan di Kota Batu berdampak pada tingginya permintaan pasar tehadap produk yang dihasilkan oleh Rumah Pemberdayaan "Susu" - Batu, akan tetapi usaha ini mengalami kesulitan dalam meningkatkan volume produksinya karena proses produksi masih dilakukan secara tradisional.

Dalam perkembangannya, Usaha Mikro Kecil dan Menengah (UMKM) Lucky Milk yang juga berkecimpung dalam industri makanan dan minuman hasil olahan susu ikut berpartisipasi dalam pemberdayaan masyarakat sekitar. Didirikan oleh Bambang Irawan pada tahun 2012 yang berlokasi di Jalan Bromo Kecamatan Sisir, Kota Batu dengan jumlah tenaga kerja sebanyak 8 orang. Produk olahan susu yang diproduksi antara lain noga susu, es yoghurt, martabak susu, resoles susu dan kerupuk susu.Pendidikan terakhir anggota mayoritas SD (25 persen), SLTP (37,5 persen), SLTA (12,5 persen) dan S1 (25 persen). Seluruh karyawan berjenis kelamin perempuan yang bekerja setiap hari Senin -
Sabtu sesuai dengan target produksi yang telah ditetapkan.Untuk memenuhi kebutuhan produksi dibutuhkan susu segar sebanyak 50 liter/hari untuk menghasilkan noga susu sebanyak $6 \mathrm{~kg}$, 500 bungkus es yoghurt, 30 pack martabak susu, 30 pack resoles susu dan $5 \mathrm{~kg}$ kerupuk susu. Seluruh proses produksi dilakukan di rumah produksi dengan peralatan yang masih tradisional. Sarana dan prasarana produksi yang masih sederhana menyebabkan kapasitas produksi sulit untuk ditingkatkan meskipun permintaan pasar terhadap produk yang dihasilkan oleh Lucky Milk sangat tinggi.

Manfaat kewirausahaan dalam pembangunan nasional berkaitan dengan penciptaan kesejahteraan melalui inovasi barang dan jasa hingga terciptanya pasar baru, berdampak pada peningkatan lapangan kerja, pendapatan perkapita, dan terciptanya pertumbuhan ekonomi. Dengan demikian kewirausahaan merupakan kunci pembangunan ekonomi dan input yang sangat penting dalam pembangunan suatu wilayah. Kewirausahaan mendorong pengembangan kewirausahaan itu sendiri melalui reaksi berantai ketika memperbaiki mutu dan jasa serta menambahkan suatu yang baru secara kontinyu.

\section{METODE}

Dalam upaya mengembangkan usaha olahan susu di Desa Songgokerto Kelurahan Songgokerto Kecamatan Batu, Kota Batudengan pendekatan manajemen usaha dengan maksud agar mampu berdaya saing serta meningkatkan pendapatan masyarakat, maka pengabdian kepada masyarakat ini dikemas dalam bentuk sosialisasi.

Pengabdian kepada masyarakat ini dilakukan dengan proses menjaring kebutuhan antara lain kebutuhan mitra, peran mitra, sinkronisasi jadwal kegiatan, mengembangkan solusi yang ditawarkan, mengembangkan materi sosialisasi selanjutnya pelatihan dan pendampingan kepada kelompok mitra.

Kehadiran pengabdi di lokasi pengabdian masyarakat dilakukan bertahap, mulai dari perkenalan, menyampaikan tujuan dan perijinan sampai seluruh data yang diperlukan terkumpul. Pengabdi juga berperan sebagai instrumen pengumpul data dalam focus group discussion pengembangan usaha olahan susu di Desa Songgokerto Kelurahan Songgokerto Kecamatan Batu, Kota Batu; dan review sejawat terhadap hasil pengabdian. 


\section{HASIL DAN PEMBAHASAN}

Kegiatan mengembangkan usaha pengolahan susu segar menjadi berbagai produk olahan susu yang memiliki nilai ekonomis tinggi dengan menggunakan konsep pemberdayaan masyarakat berbasis ekonomi kerakyatan di Desa Songgokerto Kelurahan Songgokerto Kecamatan Batu, Kota Batu dengan pendekatan manajemen usaha dan inovasi produk terdiri dari kegiatan yaitu: kegiatan koordinasi dan sinkronisasi jadwal dan tempat serta materi sosialisasi.Adapun hasil dan pembahasannya terpapar di bawah ini:

Kegiatan koordinasi dan sinkronisasi jadwal dan tempat sosialisasi serta materi sosialisasi pembuatan aneka olahan susu. Pada kegiatan awal ini, koordinasi masih bersifat umum, belum ke teknis per kegiatan. Karena koordinasi teknis per kegiatan dilakukan setiap awal kegiatan pelatihan dan pendampingan. Koordinasi awal ini mengarah pada kesepakatan umum tentang jadwal dan tempat pelatihan. Hal ini bertujuan agar anggota kelompok usaha aneka olahan susu bisa hadir dan tidak berbenturan dengan kegiatan lain. Sedangkan Sinkronisasi materi sosialisasi disusun didasarkan atas analisis kebutuhan peserta yang dilaksanakan melalui tanya jawab (diskusi) dengan melibatkan perwakilan anggota kelompok usaha aneka olahan susu. Hal ini dilakukan untuk mengetahui lebih dalam kondisi usaha dan kebutuhan mereka. Dengan demikian materi sosialisasi betul-betul sesuai kebutuhan dan pelatihannya bisa berjalan efektif dan efisien. Dalam hal ini peserta (anggota kelompok usaha pemberdayaan rumah susu dan Lucky Milk) juga diharapkan mampu menginventaris berbagai barang/bahan yang akan diperlukan dalam setiap sosialisasi.

Hasil yang diharapkan adalah produk hasil olahan susu yang diproduksi oleh mitra lebih diminati oleh pembeli, karena lebih variatif dan menggunakan bauran pemasaran yang tepat. Hasil sosialisasi menunjukkan: Adanya pengetahuan tentang bauran mix dapat meningkatkan harga/Price karena pengaruhnya kepada peningkatan volume penjualan sangat besar serta harga merupakan variabel yang penting dalam rangka meningkatkan kompetitif advantage dalam suatu kegiatan usaha. Apabila hal tersebut dapat ditingkatkan maka akan memberikan keuntungan yang besar bagi perusahaan, karena dengan semakin meningkatnya volume penjualan maka akan membentuk market share yang besar bagi kegiatan usaha.

\section{KESIMPULAN}

Kesimpulan yang diperoleh dari hasil kegiatan pengabdian masyarakat ini adalah bahwa masyarakat (kelompok usaha olahan susu) di Desa Songgokerto Kelurahan Songgokerto Kecamatan Batu, Kota Batu sangat tertarik dan termotivasi mengembangkan usahanya melalui manajemen usaha dan inovasi produk dengan cara mengikuti sosialisasi.

\section{DAFTAR PUSTAKA}

Alma, B. 2000. Kewirausahaan. Bandung: Penerbit Alfabeta.

Dirjen Pendidikan Nonformal dan Informal, 2010.

Hadiati, S. 2008, Perilaku Wirausaha Industri Keramik Berskala Kecil untuk Meningkatkan Daya Saing Produk di Malang, Jurnal Manajemen Dan Kewirausahaan, Vol.10, No. 2, September 2008: 115-123.

Lastriyanto, A. 2016. Peranan Inovasi Teknologi dalam Pengembangan Bisnis dan Pemberdayaan Wirausaha Pemula di Kota Malang. Lokakarya. Badan Perencanaan Pembangunan Daerah (BAPPEDA) Kota Malang.

Munandar, A. 2012. http://www.uinmalang.ac.id/index.php?option=com conten t \&view=article\&id=2883:\%20peran-ukmdalam-pertumbuhan-ekonomi-bangsa \& catid = 35: artikel-dosen\&Itemid $=210$. Kamis, 7 Maret 2013.

Suryana, 2003. Kewirausahaan: Pedoman Praktis, Kiat dan Proses Menuju Sukses. Edisi Revisi, Jakarta: Penerbit Salemba Empat.

Suryana, Yuyus dan Kartib Bayu, 2011. Kewirausahaan: Pendekatan Karakteristik Wirausahawan Sukses, Jakarta: Penerbit Kencana, Prenada Media Group.

Wijatno,S. 2009. Pengantar Entrepreneurship, Jakarta: PT Gramedia Widiarsarana. 
6 Jurnal Pangabdhi 